\title{
DAMPAK CORPORATE GOVERNANCE TERHADAP COST OF CAPITAL DI INDUSTRI MANUFAKTUR DI INDONESIA
}

\author{
Abdurrahman Setiawan,Bhanu Kamaluddin Putra,Farah Margaretha Leon \\ Fakultas Ekonomi dan Bisnis Universitas Trisakti \\ Jalan Kyai Tapa no 1 Grogol Jakarta Barat \\ abdurrahman022001701062@std.trisakti.ac.id
}

\begin{abstract}
This research was conducted to examine the effect of corporate governance index, block ownership and director ownership of the company. The sample used in this study was manufacturing companies listed on the Indonesia Stock Exchange for the period 2014 2018. Sampling was carried out by purposive sampling to obtain 26 manufacturing companies to be examined. The dependent variable is cost of capital while the corporate governance index, block ownership and director ownership are independent variables. Sales growth, firm size, leverage, corruption index, inflation and gross domestic product as control variables. The results of this study indicate that firm size and inflation have a positive and significant influence on the cost of capital. Whereas corporate governance index, block ownership, director ownership, sales growth, leverage, corruption index and gross domestic product have no significant effect on the cost of capital. Implications for financial managers pay attention to factors that can affect the cost of capital in manufacturing companies and for investors choosing investments that can increase profits and prosperity in the future. Suggestions for further research are expected to add to the financial statement period and to add independent variables, namely earnings management and information asymmetry. In the novelty of this study, the research analysis method only until the $t$ test (Individual) didn't use robustness check as previous studies because this study didn't have outlier data.
\end{abstract}

Keywords : Block Ownership; Corporate Governance Index; Cost of Capital: Director Ownership

\begin{abstract}
Abstrak
Penelitian ini dilakukan untuk menguji pengaruh corporate governance index, block ownership dan director ownership perusahaan. Sampel yang digunakan dalam penelitian ini adalah perusahaan manufaktur yang terdaftar pada BEI periode 2014 - 2018. Pengambilan sampel dilakukan dengan purposive sampling sehingga didapatkan 26 perusahaan manufaktur yang akan diteliti. Variabel dependen yaitu cost of capital sedangkan corporate governance index, block ownership dan director ownership sebagai variabel independen. Sales growth, firm size, leverage, corruption index, inflation dan gross domestic product sebagai variabel kontrol. Hasil penelitian ini menunjukkan bahwa firm size dan inflation memiliki pengaruh positif dan signfikan terhadap cost of capital. Sedangkan corporate governance index, block ownership, director ownership, sales growth, leverage, corruption index dan gross domestic product tidak memiliki pengaruh terhadap cost of capital. Implikasi bagi manajer keuangan memperhatikan faktor yang dapat mempengaruhi cost of capital di perusahaan manufaktur dan bagi investor memilih investasi yang bisa meningkatkan keuntungan dan kesejahteraan dimasa yang akan datang. Saran untuk penelitian selanjutnya diharapkan menambah periode laporan keuangan serta menambah variabel independen yaitu manajemen laba dan asimetri informasi. Dalam kebaruan studi ini, metode analisis penelitian hanya sampai uji $\mathrm{t}$ (Individu) tidak menggunakan Robustness Check seperti penelitian sebelumnya karena studi ini tidak memiliki data yang outlier.
\end{abstract}

Kata Kunci : Biaya Modal; Indeks Tata Kelola; Kepemilikan Blockholder; Kepemilikan Direksi 
salah satu motor penggerak ekonomi nasional. Berbagai langkah strategis telah djalankan guna meningkatkan daya saing sekaligus memperkuat strukturnya. Kemenperin optimis terhadap kinerja industri manufaktur pada tahun 2020 masih tumbuh positif, meskipun di kondisi global yang belum pasti. Sedangkan di tahun 2020 di proyeksi bisa menyentuh di angka $4.80 \%$ - $5.30 \%$. Target peningkatan tersebut seiring melonjaknya produktivitas sejumlah sektoral melalui penambahan investasi. (https://uww.kemenperin.go.id).

Otoritas Jasa Keuangan (OJK)

mendorong penerapan tata kelola perusahaan yang baik (Good Corporate Governance/GCG) oleh perusahaan di Indonesia. Pasalnya, penerapan Good Corporate Governance di Indonesia saat ini realif tertinggal dibandingkan negara-negara di kawasan ASEAN. Ketua Dewan Komisioner OJK Wimboh Santoso mengungkapkan, hanya dua emiten dari Indonesia yang masuk dalam daftar 50 Emiten Terbaik dalam Praktik Good Corporate Governance di ASEAN dalam ajang penganugerahan ASEAN Corporate Governance Awards 2015 yang diselenggarakan oleh ASEAN Capital Markets Forum (ACMF) di Manila, Filipina. Kedua emiten tersebut yaitu PT Bank Danamon Tbk dan PT Bank CIMB Niaga Tbk. Ketua Dewan Komisioner OJK juga mengungkapkan bahwa penerapan Good Corporate Governance yang baik adalah aspek utama untuk membangun fundamental perusahaan yang kokoh. Kinerja keuangan perusahaan tidak akan berkelanjutan bila tidak dilandasi oleh praktik-praktik tata kelola yang baik. Selain itu, dalam menilai laporan tahunan yang didukung Good Corporate Governance akan meningkatkan transparansi dan akuntabilitas publik, yang pada gilirannya akan meningkatkan kepercayaan investor (https://uww.cnnindonesia.com).

Penelitian yang di lakukan oleh Chen et al., (2011) dan Tran, (2014) pentingnya Corporate Governance dalam hal memeriksa berbagai aspek Performance. Namun, terlepas dari relevansinya, penelitian tersebut memeriksa sejauh mana Corporate Governance mendorong Cost of Capital tetap langka. Corporate Governance yang lemah dapat menyebabkan Cost of Capital yang lebih besar untuk hutang yang lebih tinggi. Karena itu,
Stokeholder dan Ownerships membutuhkan pengetahuan yang lebih baik tentang aturan Corporate Governance di perusahaan serta di negara tempat untuk berinvestasi. Apalagi Stokeholders dan Ownerships juga perlu mengetahui apakah perusahaan yang akan di investasikan memiliki sistem pemantauan yang baik untuk memastikan bahwa manajemen benar-benar mewakili kepentingannya.

Cost of Capita/ terdiri dari faktor penting dalam kinerja perusahaan. Jika biaya pinjaman dana tinggi, ini akan berdampak pada kinerja perusahaan. Konsep ini juga terkait dengan karakteristik negara lain. Corpotate Governance bervariasi secara mendasar di seluruh negara karena perbedaannya dalam dasar hukum (Siddiqui, 2015). Tujuan dari penelitian untuk melihat pengaruh variabel independe yaitu Corporate Governance Index, Block Ownership, Director Ownership. Serta variabel kontrol yaitu Sales Growth, Firm Sże, Leverage, Corruption Index, Inflation dan Gross Domestic Product terhadap Cost of Capital. Oleh karena itu, penelitian ini memperluas literatur dengan mengeksplorasi efek Corporate Governance pada cost of Capital perusahaan dengan menilai tingkat kepatuhan dan pengungkapan prinsip-prinsip Corporate Governance.

\section{Tinjauan Pustaka}

Konsep Cost of Capitalatau biaya modal sangat penting dalam pembelajaan perusahaan yang dimaksudkan untuk menentukan besarnya biaya secara rill yang ditanggung perusahaan dalam memperoleh sumber dana. Tedapat anggapan bahwa biaya penggunaan hutang adalah sebesar tingkat bunga yang ditetapkan dalam kontrak. Hal ini benar apabila biaya yang diterima sama besarnya dengan jumlah nominal hutangnya, tetapi sering terjadi bahwa jumlah uang diterima lebih kecil daripada jumlah nominal hutangnya (Hasan, 2013). Menurut Zhu, (2014) Good Corporate Governance dapat secara positif mempengaruhi nilai perusahaan melalui dua saluran. Saluran pertama melalui peningkatan arus kas yang diharapkan karena Corporate Governance yang baik dapat menyelaraskan tujuan manajemen dengan pemegang saham dan meningkatkan peluang pertumbuhan di masa depan. Saluran kedua melalui pengurangan biaya modal karena Corporate Governance yang baik dapat 
mengurangi pengambilalihan oleh orang dalam dan risiko informasi, oleh karena itu menyebabkan biaya pembiayaan eksternal yang lebih rendah. Hasil penelitian yang di lakukan oleh Wiliandri, (2011) Blockholder didefinisikan sebagai shareholder yang kepemilikannya paling sedikit $5 \%$ atas saham perusahaan. Dalam studi yang di lakukan oleh Ntim \& Soobaroyen, (2013) menemukan bahwa perusahaan yang mengalami kenaikan Block Ownership cenderung berkurang pengungkapan sukarela terkait Corporate Governance, kemungkinan ini pemilik menginginkan lebih terkait informasi kinerja para Block Ownership. Hasil penelitian sebelumnya yang dilakukan oleh AlHares, (2020), menemukan bahwa Director Ownership berpengaruh negatif signifikan terhadap Cost of Capital. Penelitian tersebut juga menunjukkan bahwa perusahaan dengan risiko yang lebih tinggi meningkatkan biaya pinjaman mereka, dengan demikian cost of Capital akan menjadi mahal.

Sales Growth banyak digunakan untuk mengukur seberapa besar tingkat pertumbuhan pada suatu perusahaan. Suatu perusahaan yang berada dalam industri yang mempunyai laju pertumbuhan yang tinggi, harus menyediakan modal yang cukup untuk membelanjai perusahaan Gill et al., (2010). Menurut penelitian yang di lakukan oleh Soukotta, (2012) yang mengungkapkan bahwa Sales Growth memiliki pengaruh positif dan signifikan terhadap Cost of Capital. Hasil dari penelitian sebelumnya yang di lakukan oleh Agustini, (2016) menyatakan bahwa dalam hasil penelitiannya bahwa Inflasi berpengaruh positif signifikan terhadap Cost of Capital. Menurut Agustini,(2016) di hasil penelitiannya bahwa ditemukan Firm Size dapat mempengaruhi Cost of Capital sebuah perusahaan. Hasil penelitian sebelumnya yang dilakukan oleh Rajverma et al., (2019) dalam hasil penelitiannya bahwa leverage berpengaruh negatif signifikan terhadap Cost of Capital, dengan demikian perusahaan memiliki manajemen hutang yang tidak tepat dan ketidakefisienan kinerja manajer. Penelitian sebelumnya juga menyatakan bahwa Corruption Index berpengaruh negatif signifikan terhadap Cost of Capital (AlHares, 2020). Hasil dari penelitian tersebut juga menunjukkan bahwa Gross Domestic berpengaruh negatif signifikan terhadap variabel dependen yaitu Cost of Capital(AlHares, 2020).

\section{Pengembangan Hipotesa \\ Pengaruh antara Corporate Governance Index terhadap Cost of Capital}

Penelitian sebelumnya yang di lakukan oleh Zhu, (2014) Good Corporate Governance dapat secara positif mempengaruhi nilai perusahaan melalui dua saluran. Saluran pertama melalui peningkatan arus kas yang diharapkan karena Corporate Governance yang baik dapat menyelaraskan tujuan manajemen dengan pemegang saham dan meningkatkan peluang pertumbuhan di masa depan. Saluran kedua melalui pengurangan biaya modal karena Corporate Governance yang baik dapat mengurangi pengambilalihan oleh orang dalam dan risiko informasi, oleh karena itu menyebabkan biaya pembiayaan eksternal yang lebih rendah. Menurut Penelitian sebelumnya yang di lakukan oleh AlHares (2020) menyatakan bahwa Corporate Governance Index berpengaruh negatif dan signifikan terhadap variable dependen yaitu Cost of Capital.

Corporate Governance yang lebih baik meningkatkan Firm Value melalui pengaruhnya terhadap Cost of Capital. Ketika para pemegang saham atau kreditor membiayai perusahaan, maka mereka akan menghadapi risiko yaitu laba perusahaan yang tidak akan kembali kepada mereka sebagai dividen atau bunga. Pada kenyataannya para investor benar-benar menghadapi risiko diambil alih oleh pemegang saham pengendali. Semakin tinggi risiko yang mereka hadapi, semakin tinggi premi risiko yang akan mereka tuntut, maka cost of Capital di perusahaan juga akan cenderung meningkat. (Bozec \& Bozec, 2011). Hasil penelitian sebelumnya yang dilakukan oleh Suchard et al (2012) menunjukan bahwa Corporate Governance juga memainkan peran penting dalam menjelaskan Cost of Capital, maka dapat di rumuskan hipotesis pertama sebagai berikut

\section{$\mathrm{H}_{1}$ : Terdapat pengaruh antara Corporate Governance Index terhadap Cost of Capital}




\section{Pengaruh antara Block Ownership terhadap Cost of Capital}

Hasil penelitian yang di lakukan oleh AlHares, (2020) pada penelitiannya menunjukan bahwa Block Ownership berpengaruh positif dan signifikan terhadap Cost of Capital. Hal ini menunjukan bahwa Block Ownership dapat diambil dari berbagai jenis investor dan akibatknya mereka memiliki insentif yang berbeda untuk berinvestasi. Karena itu, insentif ini menghasilkan efek yang berbeda pada cost of Capital untuk perusahaan. Hasil penelitian sebelumnya menunjukan bahwa Block Ownership berpengaruh negatif signifikan terhadap Cost of Capital (Tran, 2014). Dalam studi yang di lakukan oleh Ntim \& Soobaroyen, (2013) menemukan bahwa perusahaan yang mengalami kenaikan Block Ownership cenderung berkurang pengungkapan sukarela terkait Corporate Governance, kemungkinan ini pemilik menginginkan lebih terkait informasi kinerja para Block Ownership. Maka dapat di rumuskan hipotesis kedua sebagai berikut :

$\mathrm{H}_{2}$ : Terdapat pengaruh antara Block Ownership terhadap Cost of Capital

\section{Pengaruh antara Director Ownership terhadap Cost of Capital}

Penelitian sebelumnya yang dilakukan oleh AlHares, (2020), menemukan bahwa Director Ownership berpengaruh negatif signifikan terhadap Cost of Capital. Penelitian tersebut juga menunjukkan bahwa perusahaan dengan risiko yang lebih tinggi meningkatkan biaya pinjaman mereka, dengan demikian cost of Capital akan menjadi mahal. Dalam studi sebelumnya, di temukan bahwa Director Ownership berpengaruh negatif terhadap cost of Capital Pham et al.,(2012). Menurut penelitian Babadi \& Banisaleh, (2017) yang di lakukan di perusahaan Negara Tehran yang tercatat di Bursa Efek Tehra, hasil menunjukan bahwa Director Ownership tidak memiliki pengaruh yang signifikan terhadap cost of Capital. Maka dapat di rumuskan hipotesis ketiga sebagai berikut :

$\mathrm{H}_{3}$ :Terdapat pengaruh Director Ownership terhadap Cost of Capital

Pengaruh antara Variabel Kontrol ( Sales Growth, Firm Size, Leverage, Corruption
Index, Inflation dan Gross Domestic Product ) terhadap Cost of Capital

Hasil dari penelitian yang di lakukan oleh Soukotta, (2012) mengungkapkan bahwa Sales Growth memiliki pengaruh positif dan signifikan terhadap Cost of Capital. Penelitian sebelumnya yang di lakukan oleh Agustini, (2016) menyatakan bahwa dalam hasil penelitiannya bahwa Inflation berpengaruh positif signifikan terhadap Cost of Capital. Menurut Agustini,(2016) di hasil penelitiannya bahwa ditemukan Firm Sże berpengaruh negatif dan signifikan terhadap cost of Capital sebuah perusahaan. Menurut Rajverma et al., (2019) dalam hasil penelitiannya bahwa Leverage berpengaruh negatif signifikan terhadap cost of Capital, dengan demikian perusahaan memiliki manajemen hutang yang tidak tepat dan ketidakefisienan kinerja manajer. Penelitian sebelumnya juga menyatakan bahwa Corruption Index berpengaruh negatif signifikan terhadap cost of Capital dan di penelitian tersebut juga menunjukkan bahwa Gross Domestic Product berpengaruh negatif signifikan terhadap variable dependen yaitu cost of Capital (AlHares, 2020).

$\mathrm{H}_{4}$ : Terdapat pengaruh variable control ( Sales Growth, Firm Size, Leverage, Corruption Index, Inflation dan Gross Domestic Product ) terhadap Cost of Capital

\section{Metode Penelitian}

Metode pengambilan sampel yang digunakan dalam penelitian ini adalah purposive sampling, dimana populasi yang digunakan sebagai sampel penelitian adalah perusahaan yang memenuhi kriteria tertentu. Populasi penelitian ini mencakup perusahaan industry Manufaktur yang terdaftar di Bursa Efek Indonesia selama periode 2014-2018 dengan jumlah sampel 26 perusahaan diantara ada sub sektor Consumer Goods, Miscellenaous, Basic and Chemical. Metode pengumpulan data yang digunakan adalah pengumpulan data sekunder, dimana data diperoleh secara tidak langsung dari sumber yang telah tersedia. Sumber data dalam penelitian ini diperoleh dari website Bursa Efek Indonesia (https://www.idx.co.id), untuk melihat Corruption Index diambil dari (http://www.transparancy.org), serta melihat 
tingkat inflasi yang diambil dari Kriteria data yang akan di pilh sebagai sampel (https://www.bi.go.id) dan tingkat produk penelitian berdasarkan beberapa kondisi domestik bruto tahun 2014-2018 diambil dari sebagai berikut

Badan Pusat Statistik (https://www.bps.go.id).

\section{Tabel 1}

Kriteria Pengambilan Sampel

\begin{tabular}{lc}
\hline \multicolumn{1}{c}{ Keterangan } & Jumlah \\
\hline Perusahaan Manufaktur yang terdaftar di BEI tahun $2014-2018$ & 135 \\
Perusahaan tidak membagikan dividen dalam 5 tahun (2014-2018) & $(94)$ \\
Perusahaan tidak memiliki Interest Expense didalam Laporan keuangan & $(10)$ \\
Laporan keuangan tidak dalam mata uang rupiah & $(5)$ \\
Jumlah data yang dapat dijadikan sampel & $\mathbf{2 6}$ \\
\hline
\end{tabular}

\section{Identifikasi Pengukuran Variabel}

Variabel dan pengukuran yang digunakan dalam penelitian ini untuk mengetahui hubungan antara variabel independen dan variabel kontrol terhadap variabel dependen, yang masing-masing pengukurannya adalah sebagai berikut :

Tabel 2

Identifikasi dan Pengukuran variabel

\begin{tabular}{|c|c|c|c|c|}
\hline $\begin{array}{l}\text { Jenis } \\
\text { Variabel }\end{array}$ & $\begin{array}{c}\text { Nama } \\
\text { Variabel }\end{array}$ & Simbol & $\begin{array}{l}\text { Definisi Variabel } \\
\text { Operasional }\end{array}$ & Sumber \\
\hline \multirow{3}{*}{$\begin{array}{c}\text { Variabel } \\
\text { Independen }\end{array}$} & $\begin{array}{l}\text { Corporate } \\
\text { Governance } \\
\text { Index }\end{array}$ & CGI & Government Provision Index & \multirow{3}{*}{ AlHares, (2020) } \\
\hline & $\begin{array}{c}\text { Block } \\
\text { Ownership }\end{array}$ & $\mathrm{BO}$ & $\begin{array}{l}5 \% \text { dari total saham biasa } \\
\text { dibagi jumlah total saham yang } \\
\text { beredar }\end{array}$ & \\
\hline & $\begin{array}{l}\text { Director } \\
\text { Ownership }\end{array}$ & DO & $\begin{array}{l}\text { Jumlah saham biasa dipegang } \\
\text { oleh direksi dibagi dengan } \\
\text { jumlah total saham biasa yang } \\
\text { beredar }\end{array}$ & \\
\hline $\begin{array}{l}\text { Variabel } \\
\text { Dependen }\end{array}$ & $\begin{array}{l}\text { Cost of } \\
\text { Capital }\end{array}$ & $\mathrm{COC}$ & $\begin{array}{l}\text { Weighted average Cost of } \\
\text { Equity and Cost of Debt }\end{array}$ & $\begin{array}{c}\text { Gitman dan Zutter } \\
\text { (2015) }\end{array}$ \\
\hline \multirow{3}{*}{$\begin{array}{l}\text { Variabel } \\
\text { Kontrol }\end{array}$} & Sales Growth & SG & $\frac{S_{t}-S_{t-1}}{S_{t-1}}$ & \multirow{3}{*}{ AlHares, (2020) } \\
\hline & Firm Sże & FS & Log total asset & \\
\hline & Leverage & LVG & $\frac{\text { Total Liabilities }}{\text { Total Asset }}$ & \\
\hline
\end{tabular}




\begin{tabular}{|c|c|c|c|}
\hline $\begin{array}{l}\text { Corruption } \\
\text { Index }\end{array}$ & $\begin{array}{l}\text { CORR } \\
\text { IDX }\end{array}$ & $\begin{array}{l}\text { Data diperoleh menggunakan } \\
\text { Corruption Perception Index }\end{array}$ & wh \\
\hline Inflation & INFL & $\begin{array}{l}\text { Rata-rata tingkat Inflasi tahunan } \\
\text { dari } 2014 \text { sampai } 2018\end{array}$ & www.bi.go.id \\
\hline $\begin{array}{l}\text { Gross } \\
\text { Domestic } \\
\text { Product }\end{array}$ & GDP & $\begin{array}{l}\text { Total Produk Domestik Bruto } \\
\text { tahunan dari } 2014 \text { sampai } 2018\end{array}$ & www.bps.go. \\
\hline
\end{tabular}

\section{Uji Model}

Chow test merupakan uji yang digunakan untuk memilih model yang lebih tepat digunakan dalam penelitian, yaitu model Common Effect atau model Fixed Effect. Uji Chow test berdasarkan pada hipotesis nol, tidak memiliki heterogenitas individu dan hipotesis alternatif terdapat heterogenitas pada cross section. Dalam uji Chow test dilakukan dengan hipotesis sebagai berikut:

$\mathrm{H}_{0}$ : Model yang lebih tepat adalah Common Effect.

Ha: Model yang lebih tepat adalah Fixed Effect.

Adapun kriteria pengambilan keputusannya, yaitu:

a. Jika prob. Cross section dari chi-square < 0,05 maka $\mathrm{H}_{0}$ ditolak.

b. Jika prob. Cross section dari chi-square > 0,05 maka $\mathrm{H}_{0}$ diterima.

Hausman test merupakan pengujian yang digunakan untuk memilih model yang terbaik antara model Fixed Effect atau model Random Effect. Dalam Hausman test juga dapat digunakan untuk melihat model yang memiliki heterogenitas dalam karakteristik dari masing-masing model mana yang akan digunakan antara Fixed Effect dan Random Effect. Dalam Hausman test dilakukan dengan menggunakan hipotesis sebagai berikut:

$\mathrm{H}_{0}$ : Model yang tepat adalah Random Effect (terdapat gangguan antara individu)

Ha: Model yang tepat adalah Fixed Effect (tidak ada gangguan antara individu)

Kriteria dalam pengambilan keputusan:

a. Jika prob. Cross section dari Random < 0,05 maka $\mathrm{H}_{0}$ ditolak.

b. Jika prob. Cross section dari Random > 0,05 maka $\mathrm{H}_{0}$ diterima.

Beberapa tahapan dalam pengujian data panel, sebagai berikut :

Tabel 3.

\section{Hasil Uji Model}

\begin{tabular}{cccc}
\hline Metode & Prob. & Keputusan & Keterangan \\
Chow Test & 0.0000 & $\mathrm{H}_{0}$ ditolak & Fixed Effect \\
Hausman Test & 1.0000 & $\mathrm{H}_{0}$ diterima & Random Effect \\
\hline
\end{tabular}

\section{Sumber : Data Ouput E-Views 9.0}

Dari hasil perhitungan diatas menunjukkan bahwa nilai probabilita cross section Chi-square sebesar $0.0000<0.05$, maka keputusan yang diperoleh yaitu $\mathrm{HO}$ ditolak sehingga model yang digunakan adalah fixed effect. Jika model yang dipilih adalah model dari fixed effect, maka diperlukan pengujian selanjutnya dengan menggunakan hausman test untuk menguji apakah akan menggunakan model fixed effect atau random effect. Dengan melakukan pengujian menggunakan hausman test, hasil menunjukkan bahwa nilai probabilita crosssection statistic sebesar $1.0000>0.05$, maka keputusan yang dapat diperoleh yaitu $\mathrm{HO}$ diterima sehingga model yang digunakan adalah model random effect. Dengan demikian, dapat disimpulkan bahwa dari ketiga model (Common Effect, Fxied Effect, dan Random Effect) tersebut, model Random Effect lebih baik dalam menginterpretasikan regresi data panel untuk menjawab tujuan penelitian. 


\section{Uji F (Serentak)}

Tahap pengujian ini adalah seluruh variabel independen yaitu Corporate Governance Index, Block Ownership dan Director Ownership. Variabel control yaitu Sales Growth, Firm Size, Leverage, Corruption Index, Inflation dan Gross Domestic Product yang diuji secara bersama-sama untuk melihat apakah variabel independen secara bersama-sama mempengaruhi variabel dependen yaitu cost of Capital secara signifikan.

Kriteria pengambilan keputusanya adalah sebagai berikut:

a. Apabila hasil $\mathrm{p}$-value $\mathrm{F}>0.05$ maka $\mathrm{H}_{0}$ gagal ditolak dah $\mathrm{Ha}$ ditolak. Maksud dari hal tersebut adalah secara simultan variabel-variabel independen tidak memiliki pengaruh terhadap variabel dependen, sehingga model regresi tidak layak untuk digunakan.

b. Apabila hasil p-value $\mathrm{F}<0.05$ maka $\mathrm{H}_{0}$ ditolak dan Ha diterima. Maksud dari hal tersebut adalah secara simultan variabel-variabel independen memiliki pengaruh terhadap variabel dependen, sehingga model regresi layak untuk digunakan.

Berdasarkan hasil uji $\mathrm{F}$, bahwa nilai dari probabilita F-Statistic sebesar $0.000000<0.05$ yang artinya hasil penelitian ini menunjukan bahwa secara bersama-sama variabel independen yaitu Corporate Governance Index, Block Ownership dan Director Ownership memiliki pengaruh kepada Cost of Capital sehingga model regresi tersebut layak digunakan didalam penelitian ini.

\section{Uji t (individu)}

Uji ini dilakukan untuk melihat apakah masing - masing variabel independen yaitu Corporate Governance Index, Block Ownership dan Director Ownership. Variabel control yaitu Sales Growth, Firm Sże, Leverage, Corruption Index, Inflation dan Gross Domestic Product terhadap variabel dependennya yaitu Cost of Capital. Berikut ini hipotesa dari uji T :

$\mathrm{H}_{0}$ : variabel independen dan variabel kontrol tidak memiliki pengaruh terhadap variabel dependen

$\mathrm{H}_{\mathrm{a}}$ : variabel independen dan variabel kontrol memiliki pengaruh terhadap variabel dependen

Adapun kriteria keputusannya :

- Jika sig dari $\mathrm{t}<0.05$ maka $\mathrm{H}_{0}$ ditolak

- Jika sig dari $t>0.05$ maka $\mathrm{H}_{0}$ diterima

Tabel 4

Hasil Uji T

\begin{tabular}{cccc}
\hline Variabel & Koefisien & Probabilita & Kesimpulan \\
\hline Constant & 8.291538 & 0.2100 & - \\
Corporate Governance Index & -0.107724 & 0.9134 & Tidak Signifikan \\
Block Ownerhsip & 1.683707 & 0.1061 & Tidak Signifikan \\
Director Ownership & 0.017251 & 0.8664 & Tidak Signifikan \\
Sales Growth & -0.031125 & 0.0052 & Negatif Signifikan \\
Firm Size & 0.562033 & 0.0245 & Positif Signifikan \\
Leverage & 1.177264 & 0.1122 & Tidak Signifikan \\
Corruption Index & -4.546476 & 0.0000 & Negatif Signfikan \\
Inflation & 1.31595 & 0.0000 & Positif Signifikan \\
GDP & -0.526685 & 0.4126 & Tidak Signifikan \\
\hline
\end{tabular}

Sumber : Data Ouput E-Views 9.0

Berdasarkan hasil Uji T diatas bahwa Corporate Governance Index memiliki nilai probabilita sebesar $0.9134>0.05$ yang menunjukkan pengaruh tidak signifikan. Hasil penelitian ini menyimpulkan tidak ada pengaruh Corporate Governance Index terhadap cost of Capital. Block Ownership memiliki nilai probabilita sebesar $0.1061>0.05$ yang menunjukkan pengaruh tidak signifikan. Hasil penelitian ini menyimpulkan tidak ada pengaruh Block Ownership terhadap Cost of Capital. Director Ownership memiliki nilai probabilita sebesar $0.8664>0.05$ yang menunjukkan pengaruh tidak signifikan. Hasil penelitian ini menyimpulkan tidak ada pengaruh Director Ownership terhadap Cost of Capital.

Sales Growth memiliki nilai probabilita sebesar $0.0052<0.05$ yang menunjukkan 
pengaruh signifikan. Hasil penelitian ini menyimpulkan ada pengaruh negatif dan signifikan Sales Growth terhadap cost of Capital. Firm Size memiliki nilai probabilita sebesar $0.0245<0.05$ yang menunjukkan pengaruh signifikan, besarnya koefisien yaitu 0.562033. Hasil penelitian ini menyimpulkan ada pengaruh positif dan signifikan Firm Size terhadap Cost of Capital. Leverage memiliki nilai probabilita sebesar $0.1122>0.05$ yang menunjukkan pengaruh tidak signfikan. Hasil penelitian ini menyimpulkan tidak ada pengaruh Leverage terhadap Cost of Capital. Corruption Index memiliki nilai probabilita sebesar 0.0000 $<0.05$ yang menunjukkan pengaruh signifikan. Hasil penelitiain ini menyimpulkan bahwa ada pengaruh negatif dan signifikan Corruption Index terhadap cost of Capital. Inflation memiliki nilai probabilita sebesar $0.0000<0.05$ yang menunjukkan pengaruh signifikan. Hasil penelitian ini menyimpulkan bahwa ada pengaruh positif dan signifikan Inflation terhadap Cost of Capital. Gross Domestic Product memiliki nilai probabilita sebesar $0.4126>0.05$ yang menunjukkan pengaruh tidak signifikan. Hasil penelitian ini menyimpulkan bahwa tidak ada pengaruh Gross Domestic Product terhadap Cost of Capital.

\section{Analisis Regresi Berganda}

Hasil persamaan regresi dari penelitian

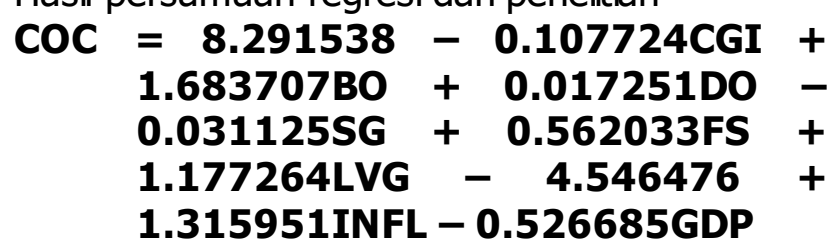

\section{Uji Goodness of Fit $\left(\mathbf{R}^{2}\right)$}

Pada tahap pengujian ini seluruh variabel independen diuji untuk melihat apakah variabel independen yaitu Corporate Governance Index, Block Ownership dan Director Ownership dan variabel control yaitu Sales Growth, Firm Sże, Leverage, Corruption Index, Inflation dan Gross Domestic Product dalam model ini mampu menjelaskan perubahan dari variabel dependen yaitu cost of Capital. Dasar keputusannya sebagai berikut :

a. Apabila nilai $\mathrm{R}^{2}$ mendekati 1 , maka hasil tersebut menunjukkan hubungan yang sangat kuat antara variabel independen dan variabel kontrol dengan variabel dependen.

b. Apabila nilai $\mathrm{R}^{2}$ mendekati 0 , maka hasil tersebut menunjukkan hubungan yang lemah antara variabel independen dan variabel kontrol dengan variabel dependen.

Berdasarkan hasil pengolahan didapatkan nilai dari Adjusted R-Square sebesar 0.995976 atau $99.5976 \%$, hal ini menunjukkan kemampuan dari seluruh variabel independen dan variabel control mampu menjelaskan variabel dependen sebesar $99.5976 \%$ sedangka sisanya $0.4024 \%$ djelaskan oleh variabel lainnya yang tidak terdapat dalam model.

Analisis Statistik Deskriptif dilakukan untuk menghitung variasi rata-rata (mean), standar deviasi, dan nilai tengah (median) dari variabel Independen, yaitu Corporate Governance Index, Block Ownership dan Director Ownership. Variabel Kontrol, yaitu Sales Growth, Firm Size, Leverage, Corruption Index, Inflation dan Gross Domestic Product. Variabel Dependen yaitu Cost of Capital.

\section{Tabel 5}

Statistik Deskriptif

\begin{tabular}{l|l|c|c|c|c|c|c|c|c|c|}
\hline & COC & CGI & BO & DO & SG & FS & LVG & CORIDX & INFL & GDP \\
\hline Mean & -1.037727 & 0.801228 & 0.065648 & 0.511488 & 0.184222 & 10.12993 & 0.393038 & 1.560800 & 0.046680 & 16.09678 \\
\hline Median & 0.069400 & 0.793700 & 0.037350 & 0.555300 & 0.087500 & 11.36615 & 0.369800 & 1.568200 & 0.038100 & 16.09350 \\
\hline Maximum & 1.196500 & 0.904800 & 0.373200 & 0.981800 & 9.403400 & 14.53750 & 0.751800 & 1.579800 & 0.064200 & 16.17140 \\
\hline Minimum & -30.91450 & 0.682500 & 0.005200 & 0.000200 & -0.470900 & 6.242900 & 0.133100 & 1.531500 & 0.032000 & 16.02410 \\
\hline Std. Dev. & 5.755452 & 0.049496 & 0.087963 & 0.303221 & 0.845734 & 2.606837 & 0.172383 & 0.016491 & 0.014329 & 0.052004 \\
\hline
\end{tabular}

Berdasarkan data statistik diatas, maka dapat diinterpretasikan sebagai berikut :

Dari perhitungan yang telah dilakukan bahwa Cost of Capital memiliki nilai rata-rata sebesar -1.037727 dengan standar deviasi sebesar 5.755452. Nilai maksimum Cost of Capital sebesar 1.196500 dimiliki oleh PT Merck Tbk pada tahun 2015. Nilai minimum -30.91450 
dimiliki oleh PT Multi Bintang Indonesia pada tahun 2018. Corporate Governance Index memiliki nilai rata-rata sebesar 0.801228 dengan standar deviasi sebesar 0.049496. Nilai maksimum Corporate Governance Index sebesar 0.904800 dimiliki oleh PT Richy Putra Globalindo Tbk pada tahun 2018 dan nilai minimum sebesar 0.682500 dimiliki oleh PT Nippon Indosari Corpindo Tbk pada tahun 2016. Block Ownership memiliki nilai rata-rata sebesar 0.065648 dengan standar deviasi sebesar 0.087963. Nilai maksimum Block Ownership sebesar 0.373200 yang dimiliki oleh PT Kalbe Farma Tbk pada tahun 2016 dan nilai minimum sebesar 0.005200 yang dimiliki oleh PT Lionmesh prima Tbk pada tahun 2017. Director Ownership memiliki nilai rata-rata sebesar 0.511488 dengan standar deviasi sebesar 0.303221. Nilai maksimum Director Ownership sebesar 0.981800 dimiliki oleh PT Hanjaya Mandala Sampoerna pada tahun 2014 dan nilai minimum sebesar 0.000200 yang dimiliki oleh PT Indofood Sukses Makmur Tbk pada tahun 2015.

Sales Growth memiliki nilai rata-rata sebesar 0.184222 dengan standar deviasi sebesar 0.845734. Nilai maksimum Sales Growth sebesar 9.403400 dimiliki oleh PT Astra International Tbk pada tahun 2014 dan nilai minimum sebesar -0.470900 dimiliki oleh PT Merck Tbk pada tahun 2018. Firm Sże memiliki nilai rata-rata sebesar 10.12993 dengan standar deviasi sebesar 2.606837. Nilai maksimum Firm Sże sebesar 14.53750 dimiliki oleh PT Astra International Tbk pada tahun 2018 dan nilai minimum sebesar 6.242900 dimiliki oleh PT Selamat Sampoerna Tbk pada tahun 2014. Leverage memiliki nilai rata-rata sebesar 0.393038 dengan standar deviasi sebesar 0.172383. Nilai maksimum Leverage sebesar 0.751800 yang dimiliki oleh PT Multi Bintang Indonesia pada tahun 2014 dan nilai minimum sebesar 0.133100 dimiliki oleh PT Indocement Tunggal Prakarsa Tbk pada tahun 2016. Corruption Index memiliki nilai rata-rata sebesar 1.560800 dengan standar deviasi sebesar 0.016491. Nilai maksimum Corruption Index sebesar 1.579800 pada tahun 2018 dan nilai minimum sebesar 1.531500 pada tahun 2014. Inflation memiliki nilai rata-rata sebesar 0.046680 dengan standar deviasi sebesar 0.014329 . Nilai maksimum Inflation sebesar
0.064200 pada tahun 2014 dan nilai minimum sebesar 0.032000 pada tahun 2018. Gross Domestic Product memiliki nilai rata-rata sebesar 16.09678 dengan standar deviasi sebesar 0.052004. Nilai maksimum Gross Domestic Product sebesar 16.17140 pada tahun 2018 dan nilai minimum sebesar 16.02410 pada tahun 2014.

\section{Hasil dan Pembahasan \\ $\mathrm{H}_{1}$ : Pengaruh Corporate Governance Index terhadap Cost of Capital}

Corporate Governance Index memiliki nilai probabilita sebesar $0.9134>0.05$ yang menunjukkan pengaruh tidak signifikan. Hasil penelitian ini menyimpulkan tidak ada pengaruh Corporate Governance Index terhadap Cost of Capital. Hasil ini tidak sejalan dengan penelitian yang dilakukan oleh Zhu, (2014) Good Corporate Governance dapat secara positif mempengaruhi nilai perusahaan melalui dua saluran. Saluran pertama melalui peningkatan arus kas yang diharapkan karena Corporate Governance yang baik dapat menyelaraskan tujuan manajemen dengan pemegang saham dan meningkatkan peluang pertumbuhan di masa depan. Saluran kedua melalui pengurangan biaya modal karena Corporate Governance yang baik dapat mengurangi pengambilalihan oleh orang dalam dan risiko informasi, oleh karena itu menyebabkan biaya pembiayaan eksternal yang lebih rendah.

Hasil penelitian sebelumnya yang dilakukan oleh Suchard et al (2012) menunjukan bahwa Corporate Governance juga memainkan peran penting dalam menjelaskan Cost of Capital. Corporate Governance yang lebih baik akan meningkatkan Firm Value melalui pengaruhnya terhadap Cost of Capital. Ketika para pemegang saham atau kreditor membiayai perusahaan, maka mereka akan menghadapi risiko yaitu laba perusahaan yang tidak akan kembali kepada mereka sebagai dividen atau bunga. Pada kenyataannya para investor benar-benar menghadapi risiko diambil alih oleh pemegang saham pengendali. Semakin tinggi risiko yang mereka hadapi, semakin tinggi premi risiko yang akan mereka tuntut, maka Cost of Capita/di perusahaan juga akan cenderung meningkat. (Bozec \& Bozec, 2011). 


\section{$\mathrm{H}_{2}$ : Pengaruh Block Ownership terhadap Cost of Capital}

Block Ownership memiliki nilai

probabilita sebesar $0.1061>0.05$ yang menunjukkan pengaruh tidak signifikan. Hasil penelitian ini menyimpulkan tidak ada pengaruh Block Ownership terhadap Cost of Capital. Hal ini bertentangan dengan studi yang dilakukan oleh AlHares, (2020) pada penelitiannya menunjukan bahwa Block Ownership berpengaruh positif dan signifikan terhadap Cost of Capital. Hal ini menunjukan bahwa Block Ownership dapat diambil dari berbagai jenis investor dan akibatknya mereka memiliki insentif yang berbeda untuk berinvestasi. Karena itu, insentif ini menghasilkan efek yang berbeda pada cost of Capital untuk perusahaan. Hasil penelitian sebelumnya menunjukan bahwa Block Ownership berpengaruh negatif signifikan terhadap Cost of Capital (Tran, 2014). Dalam studi yang di lakukan oleh Ntim \& Soobaroyen, (2013) menemukan bahwa perusahaan yang mengalami kenaikan Block Ownership cenderung berkurang pengungkapan sukarela terkait Corporate Governance, kemungkinan ini pemilik menginginkan lebih terkait informasi kinerja para Block Ownership.

\section{$\mathrm{H}_{3}$ : Pengaruh Director Ownership terhadap Cost of Capital}

Director Ownership memiliki nilai probabilita sebesar $0.8664>0.05$ yang menunjukkan pengaruh tidak signifikan. Hasil penelitian ini menyimpulkan tidak ada pengaruh Director Ownership terhadap Cost of Capital. Menurut penelitian sebelumnya yang dilakukan oleh AlHares, (2020), menemukan bahwa Director Ownership berpengaruh negatif signifikan terhadap Cost of Capital. Penelitian tersebut juga menunjukkan bahwa perusahaan dengan risiko yang lebih tinggi meningkatkan biaya pinjaman mereka,dengan demikian cost of Capital akan menjadi mahal. Dalam studi sebelumnya, di temukan bahwa Director Ownership berpengaruh negatif terhadap cost of Capital Pham et al.,(2012). Menurut penelitian Babadi \& Banisaleh, (2017) yang di lakukan di perusahaan Negara Tehran yang tercatat di Bursa Efek Tehra, hasil menunjukan bahwa Director Ownership tidak memiliki pengaruh yang signifikan terhadap cost of Capital yang artinya ini berarti semakin tinggi persentase kepemilikan pemegang saham direksil, menurunkan biaya ekuitas. Pemegang saham besar lebih mampu secara finansial daripada lainnya pemegang saham yang lebih kecil untuk membuat kontrol dan kepercayaan diri yang lebih baik dan mencairkan efek kepemilikan yang tidak diinginkan dan pemisahan manajemen dengan mengurangi informasiasimetri antara pengguna dan pemasok keuangan. Oleh karena itu, kepemilikan saham direksi adalah alat untuk mengurangi risiko informasi dan meningkatkan kualitas keuangan pelaporan, dan mengurangi risiko informasi juga mengurangi biaya modal saham biasa.

\section{$\mathrm{H}_{4}$ : Pengaruh Variabel kontrol ( Sales Growth, Firm Size, Leverage, Corruption Index, Inflation dan Gross Domestic Product ) terhadap Cost of Capital}

Firm Size memiliki nilai probabilita sebesar $0.0245<0.05$ yang menunjukkan pengaruh signifikan. Dari hasil koefisien menunjukkan besarnya pengaruh firm Sże terhadap Cost of Capital sebesar 0.562033 . Hasil penelitian ini menyimpulkan ada pengaruh positif dan signifikan Firm Size terhadap Cost of Capital. Hasil tersebut bertentangan dengan penelitian yang dilakukan oleh Agustini,(2016) di hasil penelitiannya bahwa ditemukan Firm Size berpengaruh negatif dan signifikan terhadap cost of Capital sebuah perusahaan. Perusahaan besar yang memiliki total aset lebih besar akan memiliki risiko kecil dibandingkan dengan perusahaan kecil. Selain itu, perusahaan yang memiliki total aset lebih besar memiliki prospek yang baik dalam periode waktu yang relative, lebih stabil dan lebih mampu menghasilkan keuntungan daripada perusahaan dengan total aset lebih rendah.

Inflation memiliki nilai probabilita sebesar $0.0000<0.05$ yang menunjukkan pengaruh signifikan. Dari hasil koefisien diatas menunjukkan bahwa besarnya pengaruh Inflation terhadap cost of Capital sebesar 1.31595. Hasil penelitian ini menyimpulkan bahwa ada pengaruh positif dan signifikan Inflation terhadap Cost of Capital. Hasil tersebut juga didukung oleh penelitian sebelumnya yang di lakukan oleh Agustini, (2016) menyatakan bahwa dalam hasil penelitiannya bahwa Inflasi berpengaruh positif 
signifikan terhadap Cost of Capital. Yang artinya ketika ada peningkatan biaya modal dalam hal terjadi maka akan ada peningkatan inflasi, dan penurunan biaya modal ketika tingkat inflasi menurun, selama inflasi tinggi para investor cenderung lebih berhati-hati dalam mengalokasikan modal investasinya terlebih untuk negara-negara yang memiliki fluktuasi inflasi yang cukup tinggi akan mengalami perubahan tingkat harga yang cepat.

Sales Growth memiliki nilai probabilita sebesar $0.0052<0.05$ yang menunjukkan pengaruh signifikan. Hasil penelitian ini menyimpulkan ada pengaruh negatif dan signifikan Sales Growth terhadap Cost of Capital. Hasil tersebut bertentangan dengan penelitian yang di lakukan oleh Soukotta, (2012) yang mengungkapkan bahwa Sales Growth memiliki penngaruh positif dan signifikan terhadap Cost of Capital. Leverage memiliki nilai probabilita sebesar $0.1122>0.05$ yang menunjukkan pengaruh tidak signfikan. Hasil penelitian ini menyimpulkan tidak ada pengaruh Leverage terhadap Cost of Capital. Menurut Rajverma et al., (2019) dalam hasil penelitiannya bahwa Leverage berpengaruh negatif signifikan terhadap Cost of Capital, dengan demikian perusahaan memiliki manajemen hutang yang tidak tepat dan ketidakefisienan kinerja manajer. Corruption Index memiliki nilai probabilita sebesar 0.0000 $<0.05$ yang menunjukkan pengaruh signifikan. Hasil penelitiain ini menyimpulkan bahwa ada pengaruh negatif dan signifikan Corruption Index terhadap Cost of Capital. Hasil penelitian juga menunjukkan bahwa Corruption Index memiliki pengaruh negatif dan signifikan terhadap Cost of Capital. Gross Domestic Product memiliki nilai probabilita sebesar $0.4126>0.05$ yang menunjukkan pengaruh tidak signifikan. Hasil penelitian ini menyimpulkan bahwa tidak ada pengaruh Gross Domestic Product terhadap Cost of Capital. Penelitian sebelumnya juga menunjukkan bahwa Gross Domestic Product berpengaruh negatif signifikan terhadap variabel dependen yaitu cost of Capital (AlHares, 2020).

\section{Kesimpulan Dan Implikasi}

Tujuan penelitian ini untuk mengetahui pengaruh Corporate Governance Index, Block Ownership, dan Director Ownership. Serta variabel kontrol yaitu Sales Growth, Firm Size, Leverage, Corruption Index, Inflation dan Gross Domestic Product terhadap Cost of Capital. Penelitian ini menggunakan 26 Perusahaan industri Manufaktur yang terdaftar di BEI pada tahun 2014 - 2018. Berdasarkan uraian pada analisis dan pembahasan sebelumnya, maka dapat disimpulkan Dari semua variabel yang diteliti, hanya variabel Firm Sże dan Inflation yang memiliki pengaruh positif dan signifikan terhadap Cost of Capital. Sedangkan variabel lain seperti Corporate Governance Index, Block Ownership, Director Ownership, Sales Growth, Leverage, Corruption Index dan Gross Domestic Product tidak memiliki pengaruh terhadap Cost of Capital.

Implikasi bagi manajer keuangan khususnya dalam menilai cost of Capital di perusahaan manufaktur sebaiknya para manajer keuangan memperhatikan faktor-faktor yang dapat mempengaruhi Cost of Capital di dalam perusahaan manufaktur. Jika perusahaan ingin memiliki biaya modal yang minimal, perusahaan harus meningkatkan penjualan sehingga bisa meminimalkan biaya modal jika nanti perusahaan ingin berinvestasi ke beberapa tipe investasi dengan menggunakan hasil dari penjualan yang meningkat setiap tahunnya. Berdasarkan hasil penelitian ini halhal yang harus di perhatikan adalah Firm Size, artinya perusahaan harus memiliki asset yang mencukupi untuk mendukung kegiatan operasional perusahaan, karena semakin besar asset yang dimiliki oleh perusahaan semakin tidak efektif perusahaan dalam mengelola keuangannya. Inflation, artinya perusahaan membuat kebijakan-kebijakan khusus ketika negara mengalami inflasi yang cukup tinggi sehingga perusahaan tidak terlalu parah ketika terkena imbas dari inflasi tersebut dengan cara efisiensi biaya, meminimalkan biaya operasional, meminimalisir biaya holding cost (biaya penyimpanan digudang) dan menaikkan harga suatu produk atau jasa. Dan untuk Investor ebaiknya para investor dalam memilih investasi yang bisa meningkatkan keuntungan dan kesejahteraan dimasa yang akan datang dengan memperhatikan faktor-faktor yang 
dapat mempengaruhi Cost of Capital dalam suatu perusahaan manufaktur. Faktorpertama yaitu Firm Size, para investor di harapkan melihat perusahaan dari total aset yang dimiliki semakin besar total aset yang dimiliki perusahaan tersebut semakin memiliki prospek yang baik dalam periode waktu yang cukup panjang, lebih stabil dan lebih mampu menghasilkan keuntungan daripada perusahaan dengan total aset lebih rendah. Faktor yang kedua ialah Inflation, karena ketika para investor ingin menginvetasikan modal mereka ke perusahaan manufaktur harus melihat keadaan dinegara tersebut ketika inflasi sedang menurun maka akan berdampaknya ke cost of Capital perusahaan yang menurun dan sebaliknya. Akan tetapi, ketika investor memiliki behavior risk seeker maka investor tersebut tidak akan melihat keadaan inflasi dalam suatu Negara karena investor percaya dengan prinsip "High Risk High Return". Sebaliknya jika behavior dari investor adalah risk averse maka para investor yang ingin menginvestasikan di suatu perusahaan yang kondisi Negara tersebut sedang inflasi maka akan membatalkan kegiatan investasi di perusahaan yang di negaranya sedang mengalami inflasi. Berdasarkan hasil penelitian yang dilakukan, penelitian ini memiliki beberapa keterbatasan, seperti Data yang disediakan didalam laporan keuangan beberapa perusahaan manufaktur kurang mencerminkan informasi yang dibutuhkan, beberapa dividen perusahaan manufaktur tidak membagikan dalam kurun waktu 5 tahun (2014-2018) sehingga hanya sedikit sampel perusahaan manufaktur, ada beberapa perusahaan manufaktur yang menggunakan mata uang asing didalam laporan keuangannya. Penelitian selanjutnya diharapkan menambah periode laporan keuangan perusahaan manufaktur agar menambah keakuratan hasil dari data tersebut, serta menambahkan variabel independen seperti manajemen laba dan asimetri informasi, menurut penelitian yang dilakukan oleh Murwaningsari, (2012) menemukan bahwa Manajemen Laba dan Asimetri Informasi berpengaruh positif dan signifikan terhadap cost of Capital.

\section{Daftar Pustaka}

Agustini, A. T. (2016). The Effect of Firm Size and Rate of Inflation on Cost of Capital: The Role of IFRS Adoption in the World. Procedia - Social and Behavioral Sciences, 219, 47-54. https://doi.org/10.1016/j.sbspro.2016.0 $\underline{4.031}$

AlHares, A. (2020). Corporate governance and cost of capital in OECD countries. International Journal of Accounting and Information Management, 28(1), 1-21. https://doi.org/10.1108/IJAIM-02-2019$\underline{0023}$

Al-Saidi, M., \& Al-Shammari, B. (2015). Ownership concentration, ownership composition and the performance of the Kuwaiti listed non-financial firms. International Journal of Commerce and Management, 25(1), 108-132. https://doi.org/10.1108/IJCOMA-07$\underline{\text { 2013-0065 }}$

Babadi, S. A., \& Banisaleh, A. (2017). Investigation of the relationship between ownership structure and cost of equity in companies listed on the Tehran Stock Exchange. International Journal of Scientific Study, 5(4), 24-28. https://doi.org/10.17354/j̈ssSI/2017/6

Bozec, Y., \& Bozec, R. (2011). Corporate governance quality and the cost of capital. International Journal of Corporate Governance, 2(3/4), 217. https://doi.org/10.1504/jicg.2011.04437 $\underline{6}$

Cahyono, D. D., Andini, R., \& Raharjo, K. (2016). Pengaruh komite audit, kepemilkan institusional, dewan komisaris, ukuran perusahaan (size), leverage (der) dan profitabilitas (roa) terhadap tindakan oenghindaran pajak (tax avoidance) pada perusahaan perbankan yang listing BEI periode tahun 2011 - 2013. 2(June). https://www.semanticscholar.org/paper/ PENGARUH-KOMITE-AUDIT\%2C- 
KEPEMILIKAN-INSTITUSIONAL\%2C-Cahyono

Chen, K. C. W., Chen, Z., \& Wei, K. C. J. (2011). Agency costs of free cash flow and the effect of shareholder rights on the implied cost of equity capital. Journal of Financial and Quantitative Analysis, 46(1), 171-207. https://doi.org/10.1017/S002210901000 $\underline{0591}$

Hasan, A. Y. (2013). Analisis Biaya Modal Terhadap Tingkat Pengembalian Investasi Pada Pt. Harimugabe Jaya. Jurnal Ilmiah WIDYA, 1(1), 45-51. https://onesearch.id/Record/IOS1492.ar ticle-112

Iswara, P. W. (2014). Corporate Governance dan Kinerja. Jurnal Akuntansi, Ekonomi Dan Manajemen Bisnis ISSN: 23377887, 2(2), 121-131. https://jurnal.polibatam.ac.id/index.php/ JAEMB/article/view/147

Murdayanti, Y. (2012). Pengaruh Gross Domestic Product, Inflasi, Suku Bunga, Money Supply, Current Account Dan Capital Account Terhadap Nilai Kurs Rupiah Indonesia - Dollar Amerika. Econosains Jurnal Online Ekonomi Dan Pendidikan, 10(1), 114-130. https://doi.org/10.21009/econosains.01 $\underline{01.09}$

Murwaningsari, E. (2012). Faktor-Faktor yang Mempengaruhi Cost of Capital (Pendekatan: Structural Equation Model). Journal of Economics and Business Airlangga, 22(2), 157-172. https://doi.org/10.1016/j.aap.2012.05.0 $\underline{27}$

Nawatmi, S. (2014). Korupsi dan pertumbuhan ekonomi negara-negara Asia Pasifik. Jurnal Bisnis Dan Ekonomi (JEB), 21(1), 73-82.

https://www.unisbank.ac.id/ojs/index.ph $\mathrm{p} / \mathrm{fe} 3 /$ article/view/3173

Ntim, C. G., \& Soobaroyen, T. (2013). Corporate governance and performance in socially responsible corporations: New empirical insights from a neoinstitutional framework. Corporate Governance: An International Review, 21(5), 468-494.

https://doi.org/10.1111/corg.12026

Pham, P. K., Suchard, J.-A., \& Zein, J. (2012). Corporate Governance and the Cost of Capital: Evidence from Australian Companies. Journal of Applied Corporate Finance, 24(3), 84-93. https://doi.org/10.1111/j.17456622.2012.00392.x

Raharjo, S. (2010). Pengaruh inflasi, nilai kurs rupiah, dan tingkat suku bunga terhadap harga saham di bursa efek indonesia. Jurnal Ekonomi, Bisnis, 1-16. https://www. neliti.com/publications/161 972/pengaruh-inflasi-nilai-kurs-rupiahdan-tingkat-suku-bunga-terhadapharga-saham-d\#cite

Rajverma, A. K., Arrawatia, R., Misra, A. K., \& Chandra, A. (2019). Ownership structure influencing the joint determination of dividend, leverage, and cost of capital. Cogent Economics and Finance, $\pi 1$ ). https://doi.org/10.1080/23322039.2019. $\underline{1600462}$

Siddiqui, S. S. (2015). The association between corporate governance and firm performance - A meta-analysis. International Journal of Accounting and Information Management, 23(3), 218237. https://doi.org/10.1108/IJAIM-042014-0023

Soukotta, A. (2012). Analisis faktor-faktor yang mempengaruhi cost of capital (Studi Perbandingan Pada Manufacture Multinational Company dan Manufacture Domestic Corporation di Bursa Efek Indonesia). Analisis faktor-faktor yang mempengaruhi cost of capital (Studi Perbandingan Pada Manufacture Multinational Company Dan Manufacture Domestic Corporation Di Bursa Efek Indonesia), 21(1), 1-17. https://doi.org/10.14710/jbs.21.1.1-17 
Suchard, J.-A., Pham, P., \& Zein, J. (2012). Corporate Governance and the Cost of Capital: Evidence from Australian Firms. Journal of Applied Corporate Finance, 24(3), 84-93. https://doi.org/10.2139/ssrn.1015986

Tran, D. H. (2014). Multiple corporate governance attributes and the cost of capital - Evidence from Germany. British Accounting Review, 46(2), 179-197. https://doi.org/10.1016/j.bar.2014.02.0 $\underline{03}$

Wiliandri, R. (2011). Pengaruh Blockholder Ownership dan Firm Size terhadap Kebijakan Hutang Perusahaan. Jurnal Ekonomi Bisnis, 2, 95-102. http://fe.um.ac.id/2009/10/01/jurnalekonomi-bisnis-th-16-no-2-juli-2011/

Zhu, F. (2014). Corporate Governance and the Cost of Capital: An International Study. International Review of Finance, 14(3), 393-429.

https://doi.org/10.1111/irfi.12034

(https://www.kemenperin.go.id)

(https://www.cnnindonesia.com) 